\title{
The challenge of self-regulation in commercial property leasing: a study of lease codes in the UK.
}

Article

Accepted Version

Hughes, C. and Crosby, N. (2012) The challenge of selfregulation in commercial property leasing: a study of lease codes in the UK. International Journal of Law in the Built Environment, 4 (1). pp. 23-44. ISSN 1756-1450 doi: https://doi.org/10.1108/17561451211211723 Available at https://centaur.reading.ac.uk/27792/

It is advisable to refer to the publisher's version if you intend to cite from the work. See Guidance on citing.

To link to this article DOI: http://dx.doi.org/10.1108/17561451211211723

Publisher: Emerald

All outputs in CentAUR are protected by Intellectual Property Rights law, including copyright law. Copyright and IPR is retained by the creators or other copyright holders. Terms and conditions for use of this material are defined in the End User Agreement.

www.reading.ac.uk/centaur 
Central Archive at the University of Reading

Reading's research outputs online 


\section{The challenge of self-regulation in commercial property}

\section{leasing}

\section{Cathy Hughes+ and Neil Crosby}

School of Real Estate and Planning

University of Reading

Whiteknights

Reading

RG6 6UD

+Corresponding author

E-mail: cathy.hughes@reading.ac.uk

Phone: $+44(0) 1183786036$

Key words: Commercial leases, self-regulation, UK

\section{Abstract}

Commercial landlords and tenants in the UK are largely free to negotiate the terms of their contract. Yet, since the property crash of 1989/90, successive governments have taken an interest in commercial leasing with the aims of improving market efficiency and fairness.

Government policy in this area has been pursued through industry self-regulation; since 1995 there have been three industry codes of practice on leasing. Yet, 15 years after the first code was launched, it is proving difficult to assess whether selfregulation on leasing has been a 'success', or even to determine how to evaluate this.

A review of literature on self-regulation suggests key criteria to explain the effectiveness (or ineffectiveness) of self-regulation. UK lease codes are analysed in the light of this literature, using the empirical research carried out by the authors on the 
operation of these codes. This analysis suggests that the lease code is failing as an effective system of self-regulation. While there are influential market actors championing the Lease Code, the fragmentation of the leasing process lessens this influence. The structures are not there to ensure implementation, monitor compliance and record views of affected stakeholders.

This suggests institutional limitations to self-regulation within the property industry. (199 words)

\section{Introduction}

Commercial property leasing operates within a wide variety of regulatory regimes across the globe. In the UK it is not heavily regulated. There are some statutory limits on certain lease provisions, and statute provides and governs the right to renew leases, but, on the whole, the UK law does not directly control the terms that the parties to a commercial lease are able to negotiate. There is not even a statutory or common law requirement for terms to be fair or reasonable.

That does not mean that UK governments have no interest in lease terms. Commercial leases contain provisions defining and affecting key aspects of the occupation of premises (as noted in Crosby et al 2006a, 2006b); these can impact on the ability of a business to develop and grow, or even to contract. Consequently commercial leasing has been linked to the government enterprise and productivity agendas. These policies have such enduring importance that successive governments have, especially since the property crash of $1989 / 90$, been willing to intervene in the commercial leasing market showing a belief that there is market failure which government action 
could help rectify. However, while the grounds for intervention have largely been linked to economic efficiency, there has been a recent shift to include ethical considerations of fairness.

Burton's (1992) report on retail leases for the Adam Smith Institute was undoubtedly influential: He concluded that severe information asymmetry in the market resulted in tenants being unable to make informed decisions. Furthermore, the rent review process was criticised for not being responsive to market forces; in particular the prevalence of upward only rent review clauses led to a distortion in rents and inefficiency in the market. This distortion of the normal market forces of supply and demand at rent review and a lack of transparency in the market led Burton to advocate government intervention in order to "make the commercial property leasing market work more efficiently according to market principles" (1992: 82).

Consequently, the (Conservative) government consulted on legislating in the specific areas of upward only rent reviews, confidentiality clauses and rent determination processes at rent review and lease renewal (DOE 1993). However the government was apparently persuaded of increasing flexibility in the market (DOE 1994), deciding not to legislate but encouraging the property industry to develop a system of self-regulation. This led to the first Code of Practice for Commercial Leases (RICS 1995), developed by a committee of stakeholders in the leasing process including organisations representing landlords, tenants and the land and law professions. Some fifteen years later, selfregulation is still the means by which leasing is held in check; the industry is currently operating the third edition of the code (Joint Working Group on Commercial Leases, 2007). 
It is proving difficult to assess whether self-regulation on leasing has been a 'success', or even to determine how to evaluate the extent to which it can be seen to be a successful system in terms of achieving policy objectives. This is despite research commissioned by the (Labour) Government from the University of Reading to monitor the operation of the successive codes. These studies found that the first code was poorly disseminated and had virtually no impact on the operation of the market (DETR 2000). The second code was better disseminated but was not seen to be directly influencing leasing negotiations or practice (Crosby et al 2005). The results of the dissemination of the third code were no better than the second, if not worse, and it was little used in actual negotiations (Crosby and Hughes 2009). Wheeler echoed these latter results in her independent survey of solicitors (Wheeler 2009).

These findings from the University of Reading have prompted various government statements which both exhort and threaten the property industry, as well as a further proposal (not enacted) to legislate (ODPM 2004). In 2005 the Budget Statement from the Chancellor of the Exchequer included the following statement:

"While the Government welcomes the recent trend towards greater market flexibility, it believes much more can be done to strengthen the impact of the code of practice on the market. It will continue to work with the industry on strengthening the code, but remains willing to pursue legislation if further movements towards greater market flexibility are not forthcoming."

HM Treasury (2005) Budget Statement, paragraph 3.119 The response to findings on the $3^{\text {rd }}$ edition of the code was a ministerial statement (Austin, 2009) which expressed disappointment that small business tenants were not 
being told about the code and that it was not a "primary tool for the negotiation of new leases" except in the hands of a few large tenants. There has been an increasing focus on small business tenants as the code has developed, to such an extent that it now appears that their awareness and 'use of the code' is the primary measure of the response of the market. The minister called on the property industry to respond or face legislation.

However, over the fifteen years spanned by the three codes, changes have taken place that would seem to be in line with government ambitions. There is increased diversity of lease lengths, including short leases without rent reviews, increased incidence of break clauses, changes to the approach to repairing liabilities and to subletting that are more subtle but significant. These changes are documented by Crosby et al (2005) and acknowledged by the various stakeholders in the process, including Government. However, the code monitoring also identified that these changes are essentially market driven, although the various incarnations of the code and the associated threats of legislation appear to have played their part in encouraging change (Crosby et al 2005).

Research into the operation of the lease codes so far has not attempted to address the wider issues of the advantages and limitations of using a voluntary solution to achieve policy aims within the commercial leasing market. This paper provides a first step in considering the lease codes in the wider context of industry self-regulation. The aim of the paper is twofold: First to provide a review of literature on industry self-regulation which sets out the key issues and, in particular, suggests key criteria to explain the effectiveness (or ineffectiveness) of self-regulation. Second, to consider the UK 
commercial lease codes in the light of this literature and criteria, using the existing empirical research carried out by the authors on the operation of these codes. We hope to then have the beginning of a clearer understanding of the role self-regulation can play in commercial leasing, make some preliminary conclusions on the success of these codes and suggest further research.

\section{Self-regulation}

\section{Definition and scope}

A commonly cited definition of industry self-regulation is "a regulatory process whereby an industry-level, as opposed to a governmental- or firm-level, organization (such as a trade association or professional society) sets and enforces rules and standards relating to the conduct of firms in the industry" (Gupta and Lad, 1983: 417) This definition doesn't preclude the involvement of government in the process, but places the primary responsibility for setting up and operating the regulatory regime with the industry body. For Hemphill (1992), key characteristics are that the development of self-regulation is voluntary and that it covers behaviour that is discretionary.

The scope of self-regulation is wide, as it attempts to deal with various aspects of market failure. Gunningham and Rees (1997) make a distinction between economic and social self-regulation, the former being about controlling the market and the latter about externalities i.e. the unacceptable consequences of business activities for the environment, workforce, customers or clients. It is the latter that concerns us in the current study. 
Durkheim (1933) saw mediating institutions, such as industry organisations, being in a good position to promote shared ethical practices within an industry. He saw them as 'moralising' industrial and commercial life by creating a normative framework. Adding to this moral leadership, proponents of self-regulation argue that codes can deal with moral issues that governments find difficult to tackle or define, such as taste and decency and (in the case of the advertising industry at least) can even be tougher than legislation (Boddewyn, 1985). Boddewyn further argues, through his study of the advertising industry, that because an industry has a sense of ownership of the rules on behaviour, they are accepted and enforced from within the industry without the hostile response that often accompanies legal solutions. Braithwaite (1993) argues that this sense of commitment can achieve better results than government regulation. However, self-regulation is not without its critics. Braithwaite exemplified much of the criticisms in saying that self-regulation is "frequently an attempt to deceive the public into believing in the responsibility of a[n] irresponsible industry. Sometimes it is a strategy to give the government an excuse for not doing its job." (1993: 91). Gunningham and Rees (1997) similarly note that it can be seen as a mechanism to ward off state intervention. They also report an accusation sometimes levelled at selfregulation that it serves the industry rather than the public interest. The European Consumer Law Group made plain its view that voluntary codes are a last resort for consumer protection and that "the mere existence of a code can seriously undermine the case for future legislative reform" (ECLG 1983: 211). Clearly, self-regulation has the potential to be self-serving but as Gunningham and Rees note, the important questions are about the circumstances in which industry self-regulation is self-serving 
and, alternatively, under what circumstances it may become a "force for moral constraint and aspiration in industrial and commercial life" (1997: 373).

\section{Government intervention as an alternative}

Concerns about self-regulation should not be taken to suggest that government regulation would necessarily do a better job. Equally powerful unease over government intervention in markets includes the belief that regulators can never be impartial and will always be serving particular interests; they may be 'captured' by

vested interests and so not serve the public interest (Stigler 1971). Weatherill (2007) voices the wider concerns that emanate from public choice theory and the work of Buchanan and Tullock (1962). From this economic perspective there is an assumption of self interest on behalf of regulators, again denying the presumption of impartiality. As Weatherill notes, where they are within the political system, regulators are ultimately concerned with pleasing their electorate and may respond to the latter's (mis)perceptions of risk in regulating (2007).

Beyond questions of motivation, there is also the question of whether government is in a position to intervene effectively. Much of the discussion in the literature is predicated on the notion that failure of the market to achieve economic efficiency is the main reason for the state to intervene. From this perspective, the state would ideally require an accurate sense of the way in which the market has 'failed' and of the required correction. It would also have possession of the information and solutions necessary to implement this correction. A search for this ideal state creates what Demsetz called 'the Nirvana fallacy' (1969). A more pessimistic (although perhaps more realistic) view was expressed by Coase in saying that "unless we realise that we 
are choosing between social arrangements that are more or less all failures, we are not likely to make much headway" (1964: 195). As Wallis and Dollery (1999) note, when contemplating intervention, a perfect answer should not be assumed; rather the question should be whether intervening would give an answer that is more efficient that the existing market structures can achieve.

Andrews (2007) argues that intervention comes at a price and that an impact assessment is necessary to determine if there is any realistic prospect of regulation doing a better job than the market which is worthwhile in terms of net benefits, given the costs of implementation. This view seems to accord with recent government thinking as Impact Assessments (IA) are now routinely part of the regulatory process; a publicly available IA was an important part of consultation on proposed legislation on leasing in 2004 (ODPM, 2004).

The inclination of a government to regulate markets is of course essentially political and driven by ideology. Arguably this explains the Labour Government's inclusion of ethical grounds for regulation in the 2004 consultation paper. Intervention was said to be justified "if current voluntary measures were found not to be promoting greater fairness or efficiency in the property market" (ODPM 2004: para12).

However, Weatherill (2007:2) noted that the "rhetoric of deregulation", seen in the Conservative government of the 1980 s also became evident during the latter part of the Labour Party's time in government during the late 2000s. For example, the Budget Statement of 2005, while threatening legislation on commercial leasing, also showed a desire to avoid 'burdening' business with regulation: 
"The Government's strategy for closing the productivity gap in this environment has two broad strands: maintaining macroeconomic stability to help businesses and individuals plan for the future; and implementing microeconomic reforms to remove the barriers that prevent markets from functioning efficiently and flexibly. Effective and well-focused regulation can play a vital role in correcting market failures, promoting fairness and competition, and driving up standards. However, inefficient regulation can impose a significant burden on business."

HM Treasury (2005) Budget Statement, paragraph 3.2

\section{The regulation and self-regulation continuum}

Of course it is not simply about choosing between the two mechanisms. Gupta and Lad (1983) recognised that self-regulation often coexists with government oversight and also with the threat of direct regulation. Given the limitations of the alternatives then it is perhaps not surprising that attempts are often made to harness the benefits of each (while avoiding the problems). As Gunningham and Rees argue, where there is a large gap between the interests of the individual firm and that of the public, selfregulation may be bolstered by government intervention as it may not be able to bridge the gap by itself (1997:390). Government intervention may, for example, be able to ensure information is provided and specific externalities are dealt with. Boddewyn (1985) concludes that the interaction of the two is needed to control advertising behaviour, although he sees this manifesting in different solutions in different countries and different industries. Even if self-regulation can provide the mechanisms for control, Hemphill (2004) argues that the public must be kept 
informed; truthful performance metrics are all important to convince the public that there is no need for government regulation.

Gunningham and Rees (1997) developed the idea of a continuum upon which government and self-regulation interact and co-exist. The issue for them was to determine 'principles of institutional diagnosis' to design the structures of coexistence. They argued that regulation policy must respond to industry structure; this notion of responsive regulation is one largely associated with Nonet \& Selznick (1978) which has been developed and argued by others such as Ayres and Braithwaite (1995). Put simply, the idea is that some industries have the capacity for effective selfregulation while others do not and regulation should respond to this. An example cited by Gunningham and Rees to show how government might respond to an industry with the ability to self regulate is that of health care in the USA. Industry selfregulation under the auspices of the Joint Commission on Accreditation of Healthcare Organizations was eventually given a major role in determining which hospitals could get Medicare funds from the state; only hospitals accredited by them could receive these funds (1997:397).

\section{A normative framework}

Gunningham and Rees, referencing Durkheim's idea of moralising industrial life, argue that "an industry association must establish a normative framework for its members and, equally important, develop ways to ensure its efficacy." (1997: 372). The existence of an industry organisation, such as a trade association, and its role within self-regulation is not questioned and seems to be simply assumed by many researchers in this field. Gunningham and Rees (1997:373) describe the importance of the 
industry as an "organizational field", a force with the potential to bridge the gap between individual firms and society and so to instigate change. They cite examples of the chemical manufacturing industry's global Responsible Care Program and the American Institute of Nuclear Power Operations (INPO) and their success in achieving a shift in industrial morality in response to particular events and social change.

However, the notion of organizational field is more complex than simply trade organizations, and as such may be a more relevant concept in real estate where there is no single trade association to act as an umbrella organization. DiMaggio and Powell (1983: 148) define an organizational field as "those organizations that, in the aggregate, constitute a recognized area of institutional life". This casts the net wider than a single industry body and includes suppliers, competing firms, consumers, regulatory agencies and so on. Notably the Lease Code was drawn up by a working group representing these various players rather than a trade association; the relevance of this will be considered in later analysis.

The development of an industry morality and the associated normative framework is, according to Gunningham and Rees (1997: 376) an important first step in industry selfregulation. They distilled a set of principles and practices which, they argued, must be institutionalised through the development of industry -wide policies and procedures to ensure the commitment of firms. The seven features which are central to this framework are:

1. It provides a shared basis for challenging, questioning and guiding industry practices. Looking at these things from different standpoints to standard market view. 
2. It is a product of reflection and conscious deliberation.

3. It recognises multiple values and commitments. Economic self-interest is recognised but organisations are asked to become less single-minded.

4. It takes a critical standpoint - assuming practices can be changed in light of reflection.

5. It creates a framework that defines and upholds a special organisational competence such as practicing sustainable forestry or operating nuclear reactors safely and reliably.

6. There is an expectation of willing obedience but not grudging acquiescence.

7. It provides a legitimate account of the industry's activities to the public.

This clearly sets out underpinning principles as well as associated practical manifestations. Key aspects of this are open and inclusive development, continual reflection and review, willing compliance and accountability to the public.

\section{Compliance and free riders}

The issue of willing compliance, or rather the converse, is one that exercises the minds of many researchers; Gunningham and Rees argue that it is important that a system of self-regulation prevents free riders (1997: 393). If a code is brought into operation without the full involvement of the industry players then this free riding may undermine the operation of the code (and they argue that legislative backing may be needed). Alternatively if there is full agreement but some then feign compliance selfregulation can address this through peer pressure and formal sanctions.

Lennox (2004), in his study of environmental self regulatory schemes, considered how to avoid the problems that he saw when free-riders caused firms to leave the scheme, 
potentially leading to its collapse. He postulated that if participants get a benefit from taking part then they will do it even if some of the benefits spill over to nonparticipants. He identified four types of benefit that could ensure participants did not leave despite some non-compliance:

1. Operational benefits: He found that participants in the chemical industry's Responsible Care Program (RCP) actually got efficiency savings.

2. Affiliation benefits: He notes that a condition of membership of the American Chemistry Council (ACC) was participation in the RCP. Therefore he argues that if the benefits of being in ACC outweigh costs of joining and being in the RCP then firms will not leave.

3. Signalling benefits: Taking part distinguishes good firms from bad.

4. Legitimacy benefits: By being part of the scheme, a firm may become more attractive as a trading partner or in some other way get preferable treatment from suppliers etc. (For this point he refers to work of institutional scholars such as DiMaggio and Powell (1991) and North (1990)).

Lennox's work found that participants in the RCP were better off by being in it, but then so were the non-participants. Therefore despite the operational benefits, the issue remains as Hemphill (1992) notes, where the problems of free riders may put those that abide by a code at an economic disadvantage as they are bearing the cost of the 'public goods' that are effectively provided for all in the industry regardless of their contribution. Lennox found that a group of large visible firms continued to support the RCP and so ensured its continuance. "For policymakers, this raises interesting questions about how to respond to self-regulatory efforts that are in part successful and yet still suffer from free riding and opportunism." (Lennox, 2006: 687) 


\section{Evaluating the lease code}

The literature review suggests that, in order to evaluate the success (or potential) of the Lease Code as a means of achieving policy objectives, it is necessary to consider factors such as the industry structure, along with the extent to which there is an institutional morality, a robust normative framework and a mechanism to ensure compliance. We need to establish if there are robust performance metrics on the Lease Code. We can then comment on the extent to which the industry has the capacity for self-regulation, both generally and in the case of leasing in particular and whether the system of self-regulation appears to be appropriate and successful.

In this context there is a useful practical tool produced by the Canadian Office of Consumer Affairs, an organisation which has, over many years, actively promoted debate in the use of voluntary codes. This has led them to produce a guide to the development of voluntary codes (Office of Consumer Affairs, 1998) and subsequently a framework for evaluating voluntary codes (Industry Canada, 2002). Figure 1 sets out the main headings of their framework with the associated issues. For each of the issues, the framework includes a set of performance indicators which can be used to answer the various questions. The headings are Due Process, Relevance, Success and Alternative Approaches. These headings pick up the main themes of the literature and facilitate the interrogation of specific systems of self-regulation.

The concerns over due process resonate with the establishment of a normative framework discussed by Gunningham and Rees (1997). The performance indicators suggested to evaluate due process focus on the meaningful involvement of all industry players and other stakeholders, including government, in the development of the 
code. This accords with Gunningham and Rees' notion of a shared basis and a process of conscious deliberation. Similarly, such involvement should mean that there is 'willing obedience'. Overall, the notion of due process is about inclusivity in development but also about ensuring that the burden of development and implementation is fairly spread. It also includes notions of clarity in communication, fair and independent, monitoring procedures through to complaints procedures and proportional consequences of non-compliance.

Ensuring relevance reinforces the idea that an industry must be constantly reflecting and reviewing the operation of a code to refine, develop or simply scrap it if it is no longer required.

To measure the success of a code, the framework questions the measurable achievements, the behaviour of individual firms and their internal processes with respect to the code as well as the institutionalisation of the code within the industry.

Finally the section on alternative approaches questions whether the voluntary code could be reinforced or whether alternatives such as legislation would do a better job. The public perception of relevance and success, emphasised by Hemphill (2004) is also considered here.

Therefore, in the light of the literature review, this framework appears compelling as a format to use for an initial assessment of the Lease Code. In the next section we briefly set out the content and mechanics of the latest Lease Code before attempt to answer each of the questions in Fig. 1 for this specific voluntary code. 


\begin{tabular}{|c|c|}
\hline \multicolumn{2}{|c|}{ Framework for evaluating voluntary codes } \\
\hline Evaluation factor & Issues \\
\hline \multirow[t]{7}{*}{ Due Process } & $\begin{array}{l}\text { Has code development been open, transparent, fair and } \\
\text { meaningful? }\end{array}$ \\
\hline & Is the implementation of the code fair? \\
\hline & Are the requirements of the code clear? \\
\hline & Are there fair procedures for monitoring and enforcement? \\
\hline & $\begin{array}{l}\text { Are there fair procedures for dispute settlement, complaints } \\
\text { and sanctions? }\end{array}$ \\
\hline & $\begin{array}{l}\text { Is there a range of appropriate negative consequences and } \\
\text { incentives for compliance? }\end{array}$ \\
\hline & Are the negative and positive incentives used? \\
\hline \multirow[t]{2}{*}{ Relevance } & $\begin{array}{l}\text { Does the voluntary code address a fundamental problem or } \\
\text { actual need? }\end{array}$ \\
\hline & Are there competing codes or legislative instruments? \\
\hline \multirow[t]{10}{*}{ Success } & Have the objectives of the code been achieved? \\
\hline & Are the firms capable of compliance? \\
\hline & Are there incentives for compliance? \\
\hline & $\begin{array}{l}\text { Is there an industry organization or another group to develop } \\
\text { and administer the code? }\end{array}$ \\
\hline & $\begin{array}{l}\text { Are there mechanisms to hold the industry or firm accountable } \\
\text { for compliance with the code? }\end{array}$ \\
\hline & $\begin{array}{l}\text { Are there sanctions or negative consequences for non- } \\
\text { compliance? }\end{array}$ \\
\hline & Are sanctions or negative consequences used? \\
\hline & Are there unintended or negative effects of the code? \\
\hline & Are there champions of the code? \\
\hline & Has an industry code achieved wide coverage? \\
\hline \multirow{7}{*}{$\begin{array}{l}\text { Alternative } \\
\text { approaches }\end{array}$} & Has the coverage been as wide as anticipated? \\
\hline & Are the sanctions in the voluntary code adequate? \\
\hline & Does the code cover interjurisdictional situations? \\
\hline & Is there a need for uniformity of rules? \\
\hline & Does the voluntary code require additional credibility? \\
\hline & $\begin{array}{l}\text { Is independent monitoring, enforcement or adjudication } \\
\text { required? }\end{array}$ \\
\hline & $\begin{array}{l}\text { Are sufficient resources being devoted to the code (for rule } \\
\text { making, communication, monitoring, enforcement, } \\
\text { adjudication, sanctions and revision)? }\end{array}$ \\
\hline
\end{tabular}

Fig 1: Framework for evaluating voluntary codes. Source: Industry Canada 2002 


\section{Outline of current code}

The current $\left(3^{\text {rd }}\right)$ edition of the lease code has two main objectives. It promotes specific lease clauses and behaviours and has a second, more general, stated objective to "promote fairness in landlord and tenant relationships" (JWGCL 2007:1). Given that information asymmetry has been identified as a key indicator of market failure in the leasing market (Burton 1992; DETR 2000; Crosby et al 2005) the code also has an information dissemination role. Therefore, a further objective is stated to be "to ensure that parties to a lease have easy access to information explaining the commitments they are making in clear English." (JWGCL 2007:1). It consists of three parts:

1. A guide for landlords with 10 specific requirements in order for their lease to be Code-compliant;

2. A guide for occupiers, explaining terms and providing information to be used negotiating a new lease; and

3. A model Heads of Terms (which can be completed on line and downloaded).

(JWGCL, 2007)

It was developed over many months by a working group representing various stakeholders including landlords, tenant bodies, property and legal advisers and government. The group was clear that it wanted to produce a code that could be of practical use for the parties to lease transactions. This is the opening text: 
This revised lease code is the result of pan-industry discussion between representatives of landlords, tenants and government. The objective is to create a document which is clear, concise and authoritative.

However, our aims are wider. We want the lease code to be used as a checklist for negotiations before the grant of a lease and lease renewals. Landlords should be transparent about any departures from the code in a particular case and the reasons for them.

(JWGCL, 2007)

\section{Evaluation of the lease code initiative within Industry Canada framework}

The detailed answers to each of the sections set out in Fig 1 are set out in the figures below; each figure corresponds to a section of the framework. The responses to the questions for the relevant performance indicators draw on the empirical work by the authors monitoring the operation of the three editions of the code, reported respectively in DETR(2000), Crosby et al (2005) and Crosby and Hughes (2009). The section results are summarised below each figure. 


\section{Due Process}

Q. Has code development been open, transparent, fair and meaningful?

Meaningful involvement of all industry players (including SMEs) in development?

In the context of commercial leasing this is a diverse group. Industry players include

landlords and their representative bodies as well as their advisers (lawyers and property

agents). The answer is yes as these bodies were all involved in development of the $3^{\text {rd }}$ edition

as part of the working group:

The Association Of British Insurers, British Council for Offices, British Property Federation (BPF), Investment Property Forum, The Law Society of England and Wales, The Royal Institution of Chartered Surveyors (RICS), The Forum of Private Business.

Involvement of affected public (including workers, consumers, public interest groups) in development?

The key groups are those representing occupiers, large and small. These were represented in the working group in the shape of the British Retail Consortium, Confederation of British

Industry, CoreNet Global, Federation of Small Businesses,

Funding or support for SMEs or affected public?

Not that we are aware of.

Government involvement?

Yes, the relevant English government department (Communities and Local Government) and

the Welsh Assembly Government were in the working group.

Is the code publicly available?

Yes it is readily available on the web.

Did a standards development body develop the code?

Yes in the form of a working group.

What was the decision making process (eg consensus, majority voting etc)?

We have no information.

Q. Is the implementation of the code fair?

Is there an imbalance of power in the industry?

There is not really a single industry. The leasing process and consequent relationship involves solicitors and surveyors among others. There are strong individual firms of landlords that also have a strong lobbying organisation, as well as strong professional groups representing advisers. To set against this there are an unknown number of smaller landlords who are not part of any organised group.

Does the code impose different burdens on different industry members?

We have no information on the costs of implementation but would assume that there are economies of scale for larger organisations who can spread compliance input over a larger number of individual property leases

Are the rules clearly communicated to the industry and the affected public?

The monitoring research suggests not. For all three editions of the code it was found that there are problems with dissemination. For the latest edition there was a surprising lack of awareness among landlords, occupiers and their advisers with the exception of the largest landlords and occupiers.

$Q$. Are the requirements of the code clear?

Does it use plain language?

Yes, certainly the $3^{\text {rd }}$ edition makes a concerted attempt to use plain language, largely as it is aimed at small businesses be they landlords or occupiers.

Are there clear obligations on the industry?

The third edition was drafted with the intention of achieving this as the second edition had been criticised for being very vague and having little in terms of specific obligations on landlords. Typical of this earlier edition is the following example:

Both landlords and tenants should negotiate the terms of a lease openly, constructively and 
considering each other's views. ( $2^{\text {nd }}$ code).

Yet, even for the $3^{\text {rd }}$ edition, at first sight the answer is no as the home page of the website gives conflicting messages. It first gives a signal to landlords that they do not have to follow it although with a general 'government is watching' threat:

"The Code is voluntary so occupiers should be aware that not all Landlords will choose to offer Code-compliant leases. The Government, however, takes a keen interest in ensuring the property industry complies with this voluntary Code." (www.leasingbusinesspremises.co.uk 2007)

However there is a specific Landlord's Code which contain clear expectations for lease negotiations, clauses and property management such as:

"Landlords must make offers in writing which clearly state: the rent; the length of the term and any break rights; whether or not tenants will have security of tenure; the rent review arrangements; rights to assign, sublet and share the premises; repairing obligations; and the VAT status of the premises."

Some require landlords to simply respond to requests from prospective occupiers and a few are somewhat vague:

"Tenants' repairing obligations should be appropriate to the length of term and the condition of the premises."

Q. Are there fair procedures for monitoring and enforcement?

Is there a compliance policy to govern monitoring and enforcement?

Are there independent and knowledgeable third party audits?

Is there approval of the internal audit process by independent third parties?

No to all three questions - the only real monitoring is that funded by and for the Government. For the $2^{\text {nd }}$ edition of the code some of the interested parties attempted to collect data via questionnaires but this was not impartial monitoring. There is no ongoing audit at firm level or by any third party.

Q. Are there fair procedures for dispute settlement, complaints and sanctions?

Performance indicators suggested here are about the process: presence of ombudsman, process for industry and public complaints, reports of complaints, transparency of complaints process etc.

There is no process either for the industry or for occupiers to complain about the operation of, or adherence to, the code. No 'body' has any role in this regard.

$Q$. Is there a range of appropriate negative consequences and incentives for compliance? Performance indicators include proportionality, deterrent nature of consequences and incentives for compliance

There are no negative consequences at an individual firm level and similarly no firm level incentives for compliance. There is a general threat of legislation which is associated with the periodic research done for the government; however the most recent research suggested that this threat is no longer perceived as strong.

$Q$. Are the negative and positive incentives used?

As above - no incentives so cannot be used.

Fig 2: Due Process

The development process appears to have been open, transparent, fair and

meaningful with wide consultation. The resulting suite of documents contains clear

requirements for landlords during lease negotiations and during the life of a lease.

However, due process fails in two key respects. First, there is no single 'industry' to 
take on responsibilities under the code; there are several groups who need to act to make the code work by implementing its requirements. For example some lease clauses will be agreed by the landlord's property agent (such as lease term) and others (such as assignment arrangements) are likely to be the responsibility of the lawyers. The responsibility for ongoing management is likely to be given to a (different) firm of managing agents. This means that implementation is fragmented. There are no processes for monitoring and enforcement (beyond the periodic and high level monitoring commissioned by government). Similarly there are no real incentives to comply, or negative consequences for those that do not. 


\section{Relevance}

Q. Does the voluntary code address a fundamental problem or actual need?

\section{Are the objectives of the code still relevant?}

Some within the industry argue that the main objectives have largely been met through market mechanisms. The code monitoring found plenty of evidence of this view especially among letting agents. Yet, our research suggested that the reality was different in terms of information provision and lease terms. Notably, Ireland has within the last year abolished the use of upwards only rent review clauses in their commercial leases, the original catalyst issue for UK occupier pressure for lease reform in the early 1990s; given the similarity of Irish and UK lease terms, this suggests that lease reform is still a highly relevant issue in commercial property markets

\section{Can the behaviour that needs to be changed be identified?}

To a large extent the answer is yes in terms of the specific requirements of the code. The code monitoring has identified a number of issues and the Government has used these reports to identify issues such as assignment and subletting, upwards only rent reviews and the awareness of small business of the implications of signing leases where they would like behaviour to change.

Does the problem the code addressed still exist?

See above. Also work such as the Occupier Satisfaction Index (OSI) (2009) suggests there are still many problem areas.

\section{Has the code been updated to reflect changing conditions?}

Yes, the new version is quite different to its predecessors and reflects changes in leasing practices. Significantly. It is clearly targeted at smaller landlords and occupiers. It also tries to reflect the main concerns of occupiers.

Is there a process in place for evaluation and revision of the code?

The Code working group still exists but there appears to be no process for reviewing the code on an ongoing basis.

Q. Are there competing codes or legislative instruments?

No. The only confusion that might occur is between the various versions of the code: The monitoring research of the dissemination of the latest code suggested that professionals are aware of the $2^{\text {nd }}$ version and believe that to be the current edition rather than the $3^{\text {rd }}$.

Fig. 3 Relevance

Given the composition of the code working group, including representatives of several occupier groups, it perhaps can be assumed that the code is addressing issues relevant to these parties. It has been revised three times to respond to changing circumstances and the findings of research into its effectiveness. However this research has also found evidence that some landlords and many of their letting agents see no need for a code, believing that the market is self-regulating and that there is, 
therefore, no persistent market failure. Other research into landlord and tenant relations suggests that the issues underlying the charge of inefficiency, such as information asymmetry and lease clauses that restrict the operation of market forces, are still very much alive (see for example the OSI (Property Industry Alliance and Corenet global (2009)). It would also seem to still have relevance for government policies in so far as economic efficiency and fairness in commercial leasing are sought and, judging by the research to date, do not yet seem to be achieved. 
Q. Have the objectives of the code been achieved?

Performance indicators include: an increase or decrease in customer/stakeholder complaints, number of violations, achievement of measurable objectives and the reputation of industry

The answers to the questions on relevance of the code show how difficult it is to answer this question. The lack of continual monitoring or procedures for complaint adds to these difficulties. Certainly there have been changes to lease clauses which might be seen to promote fairness; however the OSI (2009) suggests there are still problems to address. In terms of dissemination - the monitoring research shows that this objective has not been achieved.

$Q$. Are the firms capable of compliance?

Performance indicators are first about the firms - their sophistication, expertise, provision of training, compliance regimes, resources given to compliance, familiarity with code requirements. Second, the industry body - its training activities, resources for monitoring etc.

The point has already been made that, although the code is largely aimed at regulating the behaviour of 'landlords', the firms involved in creating and operating a lease span several types of business. Within each group there are certainly some very large and sophisticated firms who are used to complying with regulations, for example the property advisers typically belong to the RICS and the lawyers are required to be members of the Law Society. There is some evidence of 'training' within these firms and their professional bodies have been active in dissemination to the members. The BPF, representing landlords, has similarly been active in dissemination. However there is little evidence of firms adopting compliance regimes; our research found evidence of only one firm that ensured it had procedures in place to conform to the code before using the code logo. It is also not clear the extent to which landlords (who endorse the code) ensure that their advisers and agents are using it.

Beyond the large firms, there are many SMEs in all types of business that are unaware of the code and so unlikely to score highly on these performance indicators.

$Q$. Are there incentives for compliance?

Performance indicators include: logo, financial incentives, competitive advantage, regulatory incentives, high exit costs, negative consequences for non-compliance, identification as non-complier.

There is no logo for the $3^{\text {rd }}$ edition; to show endorsement of the code agents typically put a line on the particulars such as this from a property being marketed by Jones Lang LaSalle, property agents:

LEASE CODE

British Land supports the aims and objectives of the Code of Practice for Commercial Leases in England and Wales. A copy of the Code is obtainable from your advisors or from www.commercialleasecodeew.co.uk or from the Royal Institution of Chartered Surveyors. 12 Great George Street, London, SW1P 3AD.

The advantages of compliance are not clear; there may be some reputational advantage but there is no direct evidence of this. There are certainly no specific and measurable consequences of non-compliance. Whether compliance is valued by customers is unclear without research into this.

$Q$. Is there an industry organization or another group to develop and administer the 
code?

To develop yes - but not to administer. This role is dissipated across professional bodies and industry groups who represent various players with different inputs into the leasing process.

$Q$. Are there mechanisms to hold the industry or firm accountable for compliance with the code?

Performance indicators include: complaints procedures, reports, audits

No - only the Government funded periodic research which address specific questions posited by government.

Q. Are there sanctions or negative consequences for non-compliance?

No - only a general threat of legislation

$Q$. Are sanctions or negative consequences used?

No sanctions so cannot be used.

$Q$. Are there unintended or negative effects of the code?

\section{Performance indicators such as limiting completion or uneven burden between players being imposed}

None that are apparent; there is certainly no sense that conforming to the code limits competition. Given that conforming with the code is arguably not particularly onerous then it does not overburden them.

$Q$. Are there champions of the code?

Do leaders support, promote and apply pressure on peers to implement code? Industry leaders do publicly support and endorse the code. The landlords' lobby group, the British Property Federation (BPF) is quite vocal in encouraging members to conform. It implemented initiatives such as the Commercial Landlord Accreditation Scheme (CLAS) and the 'Pledges of support from law firms and agents', to encourage good practice in general and adoption of the Lease Code in particular.

The Royal Institution for Chartered Surveyors (RICS) and the Law Society has publicised the Code through various journals, newsletters, e-bulletins etc. as well as seminars and other events. It has also introduced an initiative to encourage banks to promote the Code to small businesses. The Law Society produced a business lease, for short term lettings of simple premises, which explicitly conforms to the Code. However, the professional bodies are reluctant to apply pressure on their members. The monitoring research for the third code found that this reluctance is because they believe they cannot instruct members to undertake activities that may be 'against their clients' interests', such as giving potential tenants information on the consequences of agreeing certain lease clauses.

Q. Has an industry code achieved wide coverage?

The monitoring research suggests not

Fig. 4: Success

The success of the code is really not clear, largely because of the lack of mechanisms to implement and monitor the operation of the code at a detailed level. There are certainly organisations representing various stakeholders as well as firms and 
individuals that are championing the code; there are also firms with the expertise and capacity to implement compliance regimes. However, as discussed above, without the overall industry body to administer the scheme, the implementation is fragmented. Dissemination is the only aspect of the latest code to be investigated so far; it was found that the code was reaching even fewer tenants than its predecessor and a minority of small landlords. It is difficult to see how a code can be considered a success if it is not even reaching those to which it is aimed, regardless of any future assessment of its impact on the behaviour of those it does reach. 


\section{Alternative approaches}

Q. Has the coverage been as wide as anticipated?

The code was launched by a government minister in February 2007 and she welcomed "plans for wide dissemination of the Code" (Cooper 2007). However, the research done by Crosby and Hughes (2009) found that, despite the examples of initiatives by the BPF, RICS etc. mentioned above the dissemination of the code was poor.

Government and the various code group bodies are disappointed with the monitoring findings on this.

Q. Are the sanctions in the voluntary code adequate?

There are none

Q. Does the code cover interjurisdictional situations?

No

Q. Is there a need for uniformity of rules?

Would legislation produce uniform rules and, if so, how would such legislative rules likely be developed?

Given that there are specific actions that can be taken within the code to meet objectives, these could be developed into a set of legislative rules. Other countries (such as Australia )have taken this approach although the operation of the legislation in Australia is controversial and has recently been subject to an Australian Productivity Commission report (2008) that discussed deregulation using the UK voluntary code model as an example.

Q. Does the voluntary code require additional credibility?

What would add to the credibility of the rules and the rule enforcement regime? The professional bodies are in a position to work with their clients to establish a set of verifiable procedures and to make many aspects of the code mandatory on their members.

Q. Is independent monitoring, enforcement or adjudication required?

Some kind of individual transaction level monitoring procedure would add weight, but it is not clear who this would be and who would pay.

$Q$. Are sufficient resources being devoted to the code (for rule making, communication, monitoring, enforcement, adjudication, sanctions and revision)?

We are not aware of any significant resources being devoted to this apart from government funding of the monitoring research. The Joint Working Group is an ad hoc group from the membership and/or administration of the various organisations and we believe they are unpaid.

Fig. 5: Alternative approaches

Given the lack of measurable success and the lack of mechanisms to implement and monitor the operation of the code, alternative approaches may seem to be necessary.

This may be legislation, some system of mandatory use by professionals and/or the introduction of a monitoring body and associated systems. However, the financing of such systems may be controversial. There are examples of where legislation has been 
used to regulate the process of leasing to new tenants which are worthy of analysis using a similar approach; for example, the case of retail leases/tenants in Australia (see, for example, Australian Government Productivity Commission (2008); Crosby (2007)).

\section{Conclusions}

The lease code has been developed and revised over 15 years; those involved have responded to changing circumstances and to the findings of research on its

effectiveness as well as to shifts in government priorities as fairness emerged as an objective. The third edition of the code therefore reflects a concerted effort by a wide range of stakeholders to produce a code that can be implemented and can achieve the objectives of promoting fairness and improving market efficiency by influencing lease terms and ensuring access to information.

However, despite these efforts aspects of the leasing market remain a concern and the code cannot be seen as measurably successful. There is no normative framework necessary to ensure that self-regulation works and it is not clear that there any sense of an 'industry morality'. While there are influential market actors championing the lease code, the fragmentation of the leasing process across different organizations and professions with differing priorities lessens this influence. The structures are not there to ensure implementation, monitor compliance and record views of affected stakeholders. While many firms advertise that they endorse and implement the code, it is not possible to ascertain whether they do or whether they are free-riders. 
Against all of the measures emerging from the literature, the lease code would therefore seem to be failing as an effective system of self-regulation. In the light of this literature, several reasons for this may be suggested. The leasing process involves individuals and organisations from different professions and lines of business making the organizational field highly complex. This means that there is no single governing body and responsibility for ensuring code compliance rests with individual organizations. This may distinguish this 'industry' from others that have successful schemes of self-regulation which typically have a central industry body overseeing its operation. The notion of responsive regulation would seem to suggest that the institutional structures conspire against self-regulation. The interaction between government and self-regulation may therefore be too much in favour of the latter. The threat of legislation is not perceived as strong, which may be reducing the effect of the main incentive for compliance.

The question then arises as to whether the voluntary lease code could ever work. In order to address this, research is needed into the experience of other countries in regulating the property industry by voluntary means and the regulation of other areas of UK property industry practice. There is a wealth of research into self-regulation in other industries, some of which has been mentioned in this paper; research is now needed to look more closely at the structures of these systems as well as at the experience in other property markets to assess if similar institutional difficulties exist there and (if so) could be overcome to make a success of self-regulation. 


\section{References}

Andrews, P (2007) Are market failures and IA useful? In: Weatherill, S (Ed.), Better regulation, pp. 49-81. Oxford: Hart publishing.

Austin (2009) Ministerial Statement by the Parliamentary Under-Secretary of State for Communities and Local Government, Ian Austin. London: Hansard HC 3 July 2009, c30WS.

Australian Government Productivity Commission (2008) The Market for Retail Tenancy Leases in Australia. Productivity Commission Inquiry Report No 43. Australian Government Productivity Commission: Canberra.

Ayres, I and Braithwaite, J (1995) Responsive regulation: Transcending the deregulation debate New York: Oxford University Press.

Boddewyn, J J (1985) Advertising self-regulation: Private government and agent of public policy. Journal of Public Policy \& Marketing, 4, 129-41.

Braithwaite, J (1993) Responsive regulation in Australia. In: Grabosky, P and Braithwaite, J (Eds.), Regulation and Australia's future, pp. 81-96. Canberra: Australian Institute of Criminology.

Buchanan, J M and Tullock, G (1962) The calculus of consent: Logical foundations of constitutional democracy. Michigan: University of Michigan Press.

Burton, J (1992) Retail rents: Fair and free market? London: Adam Smith Institute.

Coase, R (1964) The regulated industries: Discussion. American Economic Review, 54(3), 194-7. 
Crosby, N (2006) Australian and UK small business leases - what can we learn from each other? Australian Property Law Journal, 14(3), 297-315.

Crosby, $\mathrm{N}$ and Hughes, C (2009) Monitoring the 2007 Code for leasing business premises, London: Department for communities and local government.

Crosby, N, Hughes, C and Murdoch, S (2004) Interim report: Monitoring the 2002 Code of Practice for Commercial Leases. London: ODPM.

Crosby, N, Hughes, C and Murdoch, S (2005) Monitoring the 2002 Code of Practice for Commercial Leases. London: ODPM.

Crosby, N, Hughes, C and Murdoch, S (2006a) Flexible property leasing and the small business tenant, Journal of Property Research, 23(2), 2006, 163-88.

Crosby, N, Hughes C and Murdoch, S (2006b) Exit strategies for business tenants. Journal of Property Research, 23(3), 2006, 215-36.

Demsetz, H (1969) Information and efficiency: Another viewpoint. Journal of Law and Economics, 12(1), 1-22.

DETR (2000) Monitoring the Code of Practice for Commercial Leases. London: HMSO. DiMaggio, P J and Powell, W W (1983) The iron cage revisited: Institutional isomorphism and collective rationality in organizational fields. American Sociological Review, 48(2), 147-60.

DOE (1993) Commercial Leases. Government Consultation Paper. London: Department of the Environment. Department of the Environment (1994) Government proposes code of practice on upward only rent reviews. Press release, London. 
Durkheim, E (1933) The division of labor in society. Trans. by G. Simpson. New York: Macmillan.

European Consumer Law Group [ECLG] (1983) Nonlegislative means of consumer protection. Journal of consumer policy VI(2), 209-24.

Gupta, A K and Lad, L J (1983) Industry self-regulation: An economic, organizational, and political analysis. Academy of Management Review, 8(3), 416-25.

Gunningham, N and Rees, J (1997) Industry self-regulation, an institutional perspective. Law \& Policy, 19, 363-414.

HM Treasury (2005) Investing for our future. Budget Report - March. London : The Stationery Office

Hemphill, T A (1992) Self-regulating industry behavior: Antitrust limitations and trade association codes of conduct. Journal of Business Ethics, 11, 915-20.

Hemphill, T A (2004) Monitoring global corporate citizenship: Industry self-regulation at a crossroads. The Journal of Corporate Citizenship, 14, 81-95.

Hill Wheeler, S H (2009) The commercial leases code: Tenant's tool or landlord's token? LLM Dissertation, University of Northumbria.

Industry Canada - Office of Consumer Affairs (2002) A framework for evaluating voluntary codes, Ottowa: Government of Canada.

Joint Working Group on Commercial Leases [JWGCL] (2007) The Code for Leasing Business Premises in England and Wales 2007. RICS: London Lennox, M J (2006) The role of private decentralized institutions in sustaining industry self-regulation. Organization Science, 17(6), 677-90. 
Nonet, P and Selznick, P (1978) Law and society in transition: Toward responsive law. New York: Harper Books.

North , D C (1990) Institutions, institutional change and economic performance.

Cambridge: Cambridge University Press

Office of the Deputy Prime Minister (2004) Commercial property leases: Options for deterring or outlawing the upward only rent review clauses. London: HMSO.

Office of Consumer Affairs (1998) Voluntary codes: A guide for their development and use, Ottowa: Government of Canada.

Property Industry Alliance and Corenet global (2009) UK occupier satisfaction index, Royal Institution of Chartered Surveyors.

RICS (1995) Code of Practice for Commercial Leases in England and Wales. London: Royal Institution of Chartered Surveyors.

Stigler, G J (1971) The theory of economic regulation. The Bell Journal of Economics and Management Science, 2(1), 3-21.

Wallis, J and Dollery, B (1999) Market failure, government failure, leadership and public policy. Basingstoke: Palgrave.

Weatherill, S (2007) The challenge of better regulation. In: Weatherill, S (Ed.), Better regulation, pp. 1-17. Oxford: Hart publishing.

Wheeler, S H (2009) The commercial leases code: Tenant's tool or landlord's token? LLM Dissertation, University of Northumbria. 